\title{
The Influence of Multi-assessment Model on the Motivation of Adults' English Listening and Speaking Learning
}

\author{
Zhencong Liu \\ School of English Language, Culture and Literature, Beijing International Studies University, China \\ Ting Li \\ School of English Language, Culture and Literature, Beijing International Studies University, China \\ Huiying Diao \\ School of English Language, Culture and Literature, Beijing International Studies University, China
}

\begin{abstract}
Due to the long time away from campus, the difficulty in ensuring study time, and poor psychological condition, adults have much difficulties in learning English. The study of adult English learning motivation helps to understand the main purpose of adult English learning, and then from the actual needs of students, to improve the strategies to stimulate adult English learning. Based on the adult English listening and speaking course, this paper takes the third-grade students from Beijing International Studies University (Continual Education Institute) as an example to establish a multi-assessment model of self-assessment, peer assessment and teacher assessment, along with interview and reflective journal to explore the influence of multi-assessment model upon adult English learning. The result has shown that under the multi-assessment model, the motivation of adults to learn English is gradually changed from external factors driving to internal factors driving, from personal development to intrinsic interest. That is, they changed from being forced to learn English gradually to autonomous learning. This study further broadens the scope of the participants of the multi-assessment model and offers suggestions for adult English education in China.
\end{abstract}

Index Terms - multi-assessment, adults' English learning, English listening and speaking, learning motivation

\section{INTRODUCTION}

In order to provide more applied and compound talents for the society, adult English learners choose to continue learning English further. Due to the low proficiency of English language and the cognitive development of adult English learner, we have to change traditional assessment model into multidimensional model and attempt to guiding learning and teaching in a better way. Besides, in light of the reform of college English teaching, interaction and independency were attached much more importance in English teaching education and practice. However, many teachers failed to apply multidimensional assessment model into guiding teaching practice. Thus, the current study aims at setting up a framework of multidimensional model in teaching adult English listening and speaking.

Assessment is a very important part in education. It can be divided into assessment of learning, assessment as learning and assessment for learning in terms of evaluation purposes. Assessment is used to improve both teaching and learning, experience a sense of achievement and build up confidence. In China, the most important one is the first category, which is the final evaluation with the purpose of examining the learning effect and checking the completion of the teaching objectives. The result is usually in the form of grades or scores to report to teachers and students. The second type of evaluation is carried out in the learning process. Its main form is the self-evaluation of students based on metacognition theory. The content and method of evaluation itself help teachers and students to improve their understanding, adjust their classes and improve their teaching methods. The third category, referred to as the promotion evaluation, is to track, monitor and give the feedback during the entire learning process, including the starting point evaluation and the formative evaluation conducted during the learning process.

As it is mentioned above, assessment is one of the key sections in education practices. As for empirical studies, many domestic scholars have contributed a lot in this field. They have already proved the acceptability of multi-assessment in English education. It can be broadened into adult English learning research.

\section{LITERATURE REVIEW}

This part is going to give a brief summary of previous studies on English learning motivation. English learning motivation has been studied widely both empirically and theoretically. Li and Shao have been summarized the previous studies by employing different methodology. Li gave a quantitative and qualitative summary of the research subjects, 
contents and preference, while Shao proposed current problems and solutions of English learning motivation in China. Also, Qiu has discussed the previous studies from two major schools. Their findings will be illustrated specifically as follows:

Based on the papers on foreign language learning motivation published in 18 Chinese foreign language journals from 2004 to 2013, $\mathrm{Li}$ (2015) gives a quantitative and qualitative analysis of the research on foreign language learning motivation in the decade in China from the perspectives of research trends, subjects, contents and methodologies. She and her partner concluded the four results as following: the amount of papers about English learning motivation keeps increasing on the whole; the research perspectives are multi-disciplinary; empirical studies account for a large part, while theoretical studies account for a small part; the subjects are foreign language learners of different educational backgrounds and ages; the samples become larger and more refined; dynamic longitudinal studies develop faster than static cross-sectional ones. She discusses the limitations of the research area: the effectiveness of research achievements needs to be validated, comparisons between different learners are not enough, research perspectives should be broadened, and research trends abroad should be followed closely. Finally, the paper also proposes the directions and prospects for future research on foreign language learning motivation in China.

Meanwhile, another scholar Shao and Liu (2016) proposed the problems and solutions of domestic studies of English learning motivation. He concluded the problems from research subjects, research methodology and research contents. He found that, the study conducted about English motivation can be summarized from two perspectives: horizontal and vertical aspects. On the one hand, from the horizontal aspects, previous studies conducted among postgraduates, undergraduates, vocational school students and middle school students. On the other hand, from the vertical aspect, stay-at-home children, English majors and non-English majors, bilinguals and those who have difficulty in studying have been the research subjects. Then, from the research contents, he summarized different category of learning motivation, such as, inside and outside motivation. Gao (2003) has concluded seven kinds of motivation, they are: interests, scores, study abroad, learning situation, social responsibility, personal development, and information motivation. Besides, Shao (2016) also concluded that Wang (2003) has analyzed the influencing factors of learning motivation, inside and outside factors. About inside factors, there are gender, previous knowledge, and psychological states; for outside factors, they are more complex, such as, social environment and family background, campus and classroom environment.

In addition, according to Qiu (2005) in the summary of development of English motivation study in China, there are mainly two divisions of motivational study in psychology, namely socio-psychology and mainstream motivational psychology. In his study, it presents the features of Gardner's integrative motivation theory, along with some appraisals on it. Besides, some other main theories in this field are also referred to with a presentation of the empirical studies in the past few years both at home and abroad. Furthermore, the study also points out at last that few systematic researches have been carried out on Chinese students' motivation in learning a foreign language in the primary and middle schools.

Above all, the previous studies on English learning motivation and multi-assessment model have been summarized. We can see that scholars have been discussed the categories of English learning motivation, the current trends of studies in this field and potential problems and future expectations. However, research conducted on adult English motivation is limited, compared with other participants, especially from the assessment perspective. For the sake of better development of continual education and special learning status of adult English learners, they should be attached much more attention. Thus, this study is based on listening and speaking English class of adult English learners and employed the multi-assessment model. This paper is to figure out the influence of multi-assessment upon adult English learners and to provide suggestions for adult English education in China.

\section{TheORETICAL BACKGROUND AND METHODOLOGY}

In this part, theoretical background and methodology will be given, including research design and research questions.

\section{A. Theoretical Background}

Recent educational developments such as constructivism and multiple intelligence theories as well as society requested new trends engendered to radical change in traditional approaches of instruction and assessment. For this reason, alternative assessment approaches, compared with traditional ones derived from single assessment pattern and subject, are needed in assessing both learning process and learning product.

Multiple intelligence theory as the assessment of foreign language education has provided a new visual angle. It was proposed by Professor Howard Gardner of Harvard University in the United States in 1983 in the book "The structure of Intelligence" $(1983,1993)$. There are eight types of intelligence that can be scientifically defined: linguistic intelligence, logical-mathematical intelligence, visual-spatial intelligence, bodily-kinesthetic intelligence, musical intelligence, interpersonal intelligence, intrapersonal intelligence and natural-environmental intelligence. Everyone has different type of potential intelligence biologically. Thus, to evaluate students from one standard is not scientific and acceptable.

The foreign language assessment reform under the guidance of MI theory fully respects the individual differences of students, helps students to form learning strategies that are compatible with their own intelligence and learning styles; exerts the students' intelligent advantages, enables students to gain a sense of accomplishment in language learning; mobilizes them the potential for independent learning and collaborative learning. At the same time, teachers have truly 
realized the identity expansion from simple knowledge transfer and classroom controllers to classroom organizers, facilitators, and assessors. (Pei, 2007).

For assessment, there are many forms of assessment, such as diagnostic assessment, formative assessment, terminative assessment, subjective assessment, and objective assessment, etc. Traditionally, students are evaluated. Teachers are authoritative and unique. The diversification of foreign language assessment include the standard of educational assessment, the object of assessment, the subject of assessment, the method of assessment, and so on. Multiple intelligence theory provides a theoretical framework for the assessment reform of foreign language teaching and learning. Under the guidelines of this theory, every student can be assessed fairly and objectively.

\section{B. Participants}

This paper takes the third-grade students from Beijing International Studies University (Continuing Education College) as an example to establish a multi-evaluation model of self-evaluation, mutual evaluation and teacher evaluation. Totally, there are two classes (about 25 students) take part in the experiment. They are from grade three, majoring in English. They have different aims and targets in learning English. Certainly, they differ in English speaking and listening proficiency.

\section{Research Design}

The current study takes the third-grade students from Beijing International Studies University (Continuing Education College) as an example to establish a multi-evaluation model of self-evaluation, mutual evaluation and teacher evaluation. Totally, there are two classes (about 25 students) take part in the experiment. They are from grade three, majoring in English. They have different aims and targets in learning English. Certainly, they differ in English speaking and listening proficiency.

\section{Research Questions}

There is one key research question in the study, "can the optimized multi-evaluation system improve the motivation of students' listening and speaking learning?" Then, it follows with three specific research questions, "What are the features of adult learning motivation at the beginning of this term?" "How did adult English learners respond to multi-assessment model in class?" "What kind of reasons can be given to explain adult performance during this school term?" Research questions will work as a whole to assist to figure out the influence of multi-assessment upon adult English learners and to provide suggestions for adult English education in China.

\section{FINDINGS}

This part will answer the three specific research questions one by one and further explain the key research questions. They are "what are the features of adult learning motivation at the beginning of this term?" "How did adult English learners respond to multi-assessment model in class?" "What kind of reasons can be given to explain adult performance during this school term?"

\section{A. The Characteristics of Adult English Learning Motivation}

First of all, for exploring the characteristics of the learning motivation at the beginning of this term, the author has given out questionnaire at the beginning of this semester to find out the current problems and aims of adult English learning motivation. Questions are designed according to the types of motivation in previous studies (see appendix1).

According to the category of English learning motivation in previous studies, there are three kind of motivation, namely, instrumental motivation, which means use the target language as a tool to achieve a specific purpose; cultural motivation, which means intrinsic interest for target language culture and social responsibility in mother tongue language culture; motivation of social responsibility and it is both instrumental and cultural. In addition, there are five factors involved in this questionnaire: intrinsic interest $(\mathrm{Q} 1 \sim \mathrm{Q} 4)$; achievement $(\mathrm{Q} 5 \sim \mathrm{Q} 7)$; social responsibility (Q8 Q10); Personal development (Q11 Q15); “information and social medium” (Q16 Q18).

TABLE 1

RELIABILITY STATISTICS

\begin{tabular}{|c|c|c|}
\hline \multicolumn{2}{|c|}{ RELIABILITY STATISTICS } \\
\hline Cronbach's Alpha & $\begin{array}{c}\text { Cronbach's Alpha } \\
\text { Based on Standardized } \\
\text { Items }\end{array}$ & N of Items \\
\hline .845 & .848 & 18 \\
\hline
\end{tabular}

As illustrated in Table 1, the Cronbach's Alpha value is 0.845 , which shows that the questionnaire has high reliability. Generally speaking, the reliability of the questionnaire mainly depends on Cronbach's Alpha coefficient, $\alpha<0.7$ indicates that the reliability of the designed questionnaire is not reliable; $0.7<\alpha<0.8$ indicates that the questionnaire has certain reliability, $0.8<\alpha<0.9$ means that the reliability of the questionnaire is very good. Therefore, the selected questionnaire has high reliability to test adult English learning motivation. 
TABLE 2

COMPONENT MATRIXA

\begin{tabular}{|c|c|c|c|c|c|}
\hline & \multicolumn{5}{|l|}{ Component } \\
\hline & 1 & 2 & 3 & 4 & 5 \\
\hline 1. 你喜欢语言本身 & .240 & -.176 & .375 & -.003 & .429 \\
\hline 2. 对英语一见钟情 & .395 & .055 & .133 & -.029 & .741 \\
\hline 3. 喜欢英语文学或文化 & .109 & .576 & .710 & .093 & .193 \\
\hline 4. 喜欢英语歌曲或电影 & -.112 & .626 & .507 & -.390 & -.338 \\
\hline 5. 为提高英语成绩 & .479 & .767 & -.420 & .010 & .044 \\
\hline 6. 为升学考试或毕业证书 & .957 & -.237 & .116 & .033 & -.112 \\
\hline 7. 父母/工作要求学习英语 & -.163 & .214 & .141 & .931 & -.138 \\
\hline 8. 为了不幸负父母期望 & .479 & .767 & -.420 & .010 & .044 \\
\hline 9. 为国家富强尽力 & .957 & -.237 & .116 & .033 & -.112 \\
\hline 10. 让世界了解中国 & .957 & -.237 & .116 & .033 & -.112 \\
\hline 11. 人生路上敲门砖 & .109 & .576 & .710 & .093 & .193 \\
\hline 12. 教育/修养的象征 & -.112 & .626 & .507 & -.390 & -.338 \\
\hline 13. 为了找一份好工作 & .479 & .767 & -.420 & .010 & .044 \\
\hline 14. 英语是有用的交流工具 & .957 & -.237 & .116 & .033 & -.112 \\
\hline 15. 获得成就感 & -.163 & .214 & .141 & .931 & -.138 \\
\hline 16. 更好的学习其他专业 & .479 & .767 & -.420 & .010 & .044 \\
\hline 17. 了解世界经济发展状况 & .957 & -237 & .116 & .033 & -.112 \\
\hline 18. 了解世界前沿科技 & .957 & -.237 & .116 & .033 & -.112 \\
\hline
\end{tabular}

Extraction Method: Principal Component Analysis.

a. 5 components extracted.

As indicated in Table 2, there are five components in the questionnaire after the result is analyzed in SPSS factor analysis, which is consistent with the category of English learning motivation in previous studies. Next, the qualitative data will be analyzed in next part to see is there any difference in English learning motivation after the application of multi-assessment model.

\section{B. The Responses of Adult English Learners under Multi-assessment Model}

This part will present the responses of adult English learner during the five activities. According to their actual performance and reflective journal after each activity, students said that they generally accepted the multi-assessment model. The findings of each activity will be illustrated in this part. Totally, there are three speaking activities and two listening activities and they are organized in turns. That is, activity No.1, 3, 5 are speaking activities and activity No. 2 and 4 are listening activities.

First of all, activity No.1---"Nice to meet you". Students were asked to do a warming up in pairs. Each of students will introduce themselves to their partner and then, try to remember their partner's name, hobby or other traits. Next, each student will introduce his or her partner to the whole class. Their listening and speaking skills can be strengthened in this way. According to in class performance and after class reflection, most students said that they didn't prepare themselves well in the first peer activity. They wrote down their thought in their journal and expressed that they were not used to this new assessment model because they never tried it before. And they don't like the way to speak out to criticize other's performance, so some of them want to change the peer-assessment section. For example, one student said that "I don't have many vocabularies to describe my partner because she didn't introduce herself thoroughly and she can't find anything special to introduce herself."

Second activity will be designed their listening strategy and skills. Dialogue in listening material is about the future plan after graduation. In this section, students will be asked to fill in the blanks about the specific information and choose the suitable answer for each question. Students will finish this task in pairs. For the first listening, they do the exercise by themselves and in the second listening, they started to make some comments about their own listening problems and skills, and change their ideas about each questions. Also, some students were aware of the small tips, for example, take notes. Therefore, exchange their ideas, recognize their problems both by teachers and by peers become more important. In class, students also showed their high interests into exchanging listening skills section and share their ideas about how to deal with the difficulty in dialogue. For example, one student said, "I've learned a lot from my partner because he told me many tips and made me calm down when do listening exercise."

As for activity No.3---“Who are you really?" It's also a spoken English activity (see Figure 1). Students will be asked to do a group work of four. They work together to guess the real answer of each description of their partner. This time students will be asked to form group of four. They play the games in turn in each group. Compared with spoken activity No.2, students showed a lot of interests in this activity. The author also encouraged them to speak more about related topic. By peer assessment, students gradually accept the way to learn from each other. Thus, they are braver to face their mistakes and learn a lot from each other in a more open minded. One student made judgment towards his partner, "I'm very appreciate that you put forward many questions when guessing my real answer, which made me recognize another thinking pattern and the way to make one topic more detailed, that's good!" 
WHO ARE YOU REALLY?

\begin{tabular}{|c|l|l|l|l|}
\hline \begin{tabular}{|} 
Something I'm good \\
at now
\end{tabular} & $\begin{array}{l}\text { Something I collect } \\
\text { (or used to collect) }\end{array}$ & \multicolumn{1}{|c|}{ Aspecial trip } & $\begin{array}{l}\text { Something I like to do } \\
\text { with my friends }\end{array}$ & $\begin{array}{l}\text { Someone who } \\
\text { inspired me }\end{array}$ \\
\hline $\begin{array}{l}\text { A book that taught } \\
\text { me something special }\end{array}$ & $\begin{array}{l}\text { Something I like to do } \\
\text { by myself }\end{array}$ & $\begin{array}{l}\text { A dream I had when I } \\
\text { was in high school }\end{array}$ & $\begin{array}{l}\text { A talent I have (or } \\
\text { used to have) }\end{array}$ & A special friendship \\
\hline A pet & $\begin{array}{l}\text { Three adjectives that } \\
\text { say something about } \\
\text { me }\end{array}$ & $\begin{array}{l}\text { Something l'm bad at } \\
\text { (but I love doing it } \\
\text { anyway) }\end{array}$ & A job I've had & $\begin{array}{l}\text { Something I used to } \\
\text { want to be }\end{array}$ \\
\hline $\begin{array}{l}\text { Three nouns that say } \\
\text { something about me }\end{array}$ & $\begin{array}{l}\text { A home (or place) l've } \\
\text { lived in }\end{array}$ & $\begin{array}{l}\text { Something I liked } \\
\text { doing with my family }\end{array}$ & $\begin{array}{l}\text { Something I hate } \\
\text { having to do }\end{array}$ & A restaurant I love \\
\hline
\end{tabular}

Figure 1 Activity No.3 "Who are you really?"

During activity No.4 and No.5, students have a better understanding of the significance of multi-assessment. It has unique influence in speaking and listening class especially. In these two activities, adult English learners also work in pairs to make comments about each other's performance. For example, student A talked to student B, "When we talk about the influence of different accents, I think you give more details and examples than last time, that's great!" "I think take notes is not suitable for every listening exercise because just now, I found my partner who persisted on taking notes but she failed finally!"

In conclusion, students gradually accepted the way to make comments by others and also by teacher. Next part will present the self-assessment result and analyse the reasons why they gave such responses during five activities in this term.

\section{The Reasons for Adult English Learners' Responses}

In this part, qualitative data will be collected and analyzed to see the changes toward English learning motivation. The interview questions are as following, see table 3:

TABLE 3

INTERVIEW QUESTIONS

\begin{tabular}{l} 
(1) Do you think it necessary to combine teacher's assessment together with peer assessment? \\
(2) Do you think it interesting in English class in this term? \\
(3) Do you feel comfortable when you evaluate other's work? \\
(4) Do you have any improvement in listening and speaking class during this term? \\
\hline (5) Have your English grades been improved? \\
(6) Are you confident to make comments on other's work? \\
(7) Do you think you are a qualified peer reviewer? \\
(8) Do you have other plan to learn English? \\
(9) How multi-model help you in learning English? \\
(10) Whether you think it much more interesting or boring in multi-model assessment activities?
\end{tabular}

According to the semi-structure interview and self-assessment results, the author has three findings: lack of confidence, lack of speaking materials will lead to failure of assessment; peer assessment encouraged them a lot and they can learn from each other; students learning motivation changed from outside factors driving into inside driving, their learning motivation has been strengthened from multi-assessment model practice in this school term. Most students wrote down on their journal that at first, they can't accept the complex assessment model which they were not used to make comments about other's performance. After a short term activities, they are more likely to do peer-assessment, both from the weakness and strengths of others. More profoundly, students found that it is more efficient and significant to learn from each other. Here the author just takes two questions for interviewees as an example:

Q1: Do you think it is necessary to combine teacher evaluation with peer evaluation?

S1: "I think, um ... I think it's quite necessary, because if just the teacher do reviews, it won't give me too much attention to join in class activities, and because he is under pressure in academic research (schoolwork), it is difficult to 
notice everyone in the class. But if you add up peer assessment, and it is such a one-to-one process, that is, each classmate will give more ideas to me."

Q2: Then, Do you think you are a qualified peer reviewer?

S2: "This, uh, I can't say. Sometimes I 'm familiar with this issue, and I 'm very confident to evaluate his strengths and weaknesses. If, he may, uh, I don't know him well or I don't know his thoughts very well or if I was just lost, I don't get his point, and maybe I don't know how to make a good comment. Well, yes, and I tend to evaluate his advantages, most of them ..."

Besides, students hold the view that multi-assessment model will help them a lot. Due to encouragement from peers, relaxed classroom environment and attracted learning activities, they think that multi-assessment can be used to share learning strategies with classmates and further their relationship. That's why they choose to do multi-assessment finally and stick to it in the whole school term.

According to reflective journal, students said that, actually, they are willing to do peer-assessment, but at the very beginning, they are afraid of being judged by others. "I think it's a little bit embarrassed to judge others and at the same time, being judged by others. I feel shameful because my poor vocabulary size." "When my partner gave a better answer than me, I will fell stressed out." Also, there are some students said, they have learnt a lot from peers because of their direct comments and ideas-sharing."

As for self-assessment, the author found that, adult English learner generally make negative comments of their own even if they made great improvement. They said in their journal, "I don't know how to express myself even though I want to show my ideas with others." However, there are some students also believe in multi-assessment model for the sake of they have learnt a lot from others. Some students said, "Now I found the real significance of English, which is to communicate. I like to talk to my classmates because it can help us to build up better relationship with each other."

In conclusion, lack of confidence, lack of speaking materials will lead to failure of assessment; peer assessment encouraged them a lot and they can learn from each other; students learning motivation changed from outside factors driving into inside driving, their learning motivation has been strengthened from multi-assessment model practice in this school term.

\section{Discussion}

Based on the speaking and listening class, adult English learner, this part will discuss the reasons for above results.

First of all, according to Yang (2018) in the study of current situation of adult English learners in which she thinks that adult English learners are special in learning strategy, learning motivation and effective learning time. It can be seen during the five activities and especially in the reflective journal of self-assessment. As stated in the self-assessment section, students are regretful that they don't have too much time to study, and they are poor in English proficiency. Thus, teachers need to present more positive effects about multi-assessment model towards speaking and listening class. Prepare more games and let them know the significance of good communication with others.

Besides, the theory of communicative method helps a lot to explain the responses of adult English learners. How to evaluate one's speaking proficiency is a thorny problem in defining high level spoken English. Communicative method has shed the light in this field. Compared with traditional grammar teaching method, communicative method is based on students' real needs. Under the guidance of communicative method, tasks can be designed to achieve certain goals and mainly for expressing themselves. Adult English learners will find that all five activities are designed for their experienced learning and real life. Therefore, they learn for communicating in real life situations. Communicative method can be used to explain the popularity of multi-assessment in evaluating speaking and listening activity.

In addition, due to psychological reasons, adult English learners are unique because of their high-esteem of being judged by others in front of class. That's because they are mature psychologically and they are afraid of making mistakes. So teachers can encourage them to prepare well before every class and give them some chances to present themselves. Gradually, they will be aware that their confidence is coming back. Teachers need to make them recognize the importance of making mistakes, because during this process, students will have a high awareness of certain language points.

Last but not least, according to Kreshen's input hypothesis, adult English learners also can learn from peers. Comprehensible input will also help them a lot in second language learning. Therefore, adult English learners will find it is easier to learn from teachers and mother-tongue speakers. It gives more chances to do activities in peers or in groups. More importantly, teachers can prepare more authentic English materials to increase their comprehensible input can also their speaking materials.

\section{CONCLUSION}

In conclusion, this study makes use of the optimized model for in class assessment. During this term, students work as pairs or groups to do peer-assessment and do self-assessment after class. Based on the adult English listening and speaking course, this paper takes the third-grade students from Beijing International Studies University (Continuing Education College) as an example to establish a multi-evaluation model of self-evaluation, mutual evaluation and teacher evaluation, along with interview and reflective journal to explore the influence of multi-evaluation model upon 
adult English learning. Through five speaking and listening activities, students benefit a lot from multi-assessment model. The self-assessment result alone with semi-structure interview have shown that under the multi-evaluation model, the motivation of adults to learn English is gradually changed from external factors driving to internal driving, that is, they changed from being forced to learn English gradually to active learning. This study further broadens the scope of the participants of the multi-evaluation model and provides reference for adult English education in China. However, due to limited participants, this study just is conducted in Continuing Education School. Future research can be conducted in more wide participants to get better evidence about the influence of multi-assessment model.

\section{APPENDIX A}

亲爱的同学, 你好! 为了更近一步了解大家, 给大家提供更优质的英语课堂学习, 我们特开展本次问卷调查, 希望能得到你的真实想法与宝贵意见, 谢谢你的合作！题目选项无所谓对错, 请按照实际情况填写。本问卷实 行匿名制, 所有数据只用于统计分析, 请你放心! 谢谢你的帮助。

本问卷标题为: “成人英语学习动机调查” (你为什么学英语? ), 每一个题目都对应着五个选项: “非常不符 合”“比较不符合”“不确定”“比较符合”“非常符合”，请结合你的实际情况作出选择，并在相应的方框中打“忓”。

\begin{tabular}{|l|l|l|l|l|l|}
\hline & 非常不符合 & 比较不符合 & 不确定 & 比较符合 & 非常符合 \\
\hline 1. 你喜欢语言本身 & & & & & \\
\hline 2. 对英语一钟情 & & & & & \\
\hline 3. 喜欢英语文学或文化 & & & & & \\
\hline 4. 喜欢英语歌曲或电影 & & & & & \\
\hline 5. 为提高英语成绩 & & & & & \\
\hline 6. 为升学考试或毕业证书 & & & & & \\
\hline 7. 父母/工作要求学习英语 & & & & & \\
\hline 8. 为了不喜负父母期望 & & & & & \\
\hline 9. 为国家富强尽力 & & & & & \\
\hline 10. 让世界了解中国 & & & & & \\
\hline 11. 人生路上敲门砖 & & & & & \\
\hline 12. 教育/修养的象征 & & & & & \\
\hline 13. 为了找一份好工作 & & & & & \\
\hline 14. 英语是有用的交流工具 & & & & & \\
\hline 15. 获得成就感 & & & & & \\
\hline 16. 更好的学习其他专业 & & & & & \\
\hline 17. 了解世界经济发展状况 & & & & & \\
\hline 18. 了解世界前沿科技 & & & & & \\
\hline
\end{tabular}

如有其他原因, 请你写在这里:

再次感谢你的帮助!

\section{APPENDIX B}

Interview questions

\begin{tabular}{|l|l|}
\hline Research questions & Interviewer questions \\
\hline $\begin{array}{l}\text { 1. How receptive are students to the } \\
\text { multi-assessment model? }\end{array}$ & $\begin{array}{l}\text { (1) Do you think it necessary to combine teacher's assessment together with } \\
\text { peer assessment? } \\
\text { (2) Do you think it interesting in English class in this term? } \\
\text { (3) Do you feel comfortable when you evaluate other's work? } \\
\text { (4) Do you have any improvement in listening and speaking class during this } \\
\text { term? }\end{array}$ \\
\hline $\begin{array}{l}\text { 2. How does multi- assessment model } \\
\text { affect the motivation of adult English } \\
\text { learning? }\end{array}$ & $\begin{array}{l}\text { (5) Have your English grades been improved? } \\
\text { (6) Dou confident to make comments on other's work? }\end{array}$ \\
$\begin{array}{l}\text { 3. Why has the motivation of adult English } \\
\text { learners changed? }\end{array}$ & $\begin{array}{l}\text { (8) Do you have other plan to learn English? } \\
\text { (9) How multi-model help you in learning English? } \\
\text { (10) Whether you think it much more interesting or boring in multi-model } \\
\text { assessment activities? }\end{array}$
\end{tabular}

\section{REFERENCES}

[1] An Empirical Study on the Relationship between the Motivations and Achievements of College Students' English Learning. Proceedings of the 2019 4th International Conference on Social Sciences and Economic Development (ICSSED 2019). 
[2] Chen, L.J. (2018). The application of cognitive psychology in adult English teaching. Journal of Hubei Open Vocational College. 31(24):147-148.

[3] Dornyei, Z. (2001). Motivational Strategies in the Language Classroom. Cambridge: Cambridge University Press.

[4] Fan, D. M. (2016) .A study on the effectiveness of strategies used by College English teachers to stimulate students' learning motivation. Science and Education Guide.(12):94-95.

[5] Gardner, H. (1983). Frames of Mind: The Theory of Multiple Intelligence. New York: Basic Books.

[6] Gardner, H. (1993). Multiple Intelligences: The Theory in Practice. New York: Basic Books.

[7] G, Y. H., Zhao, Y., Cheng, Y. \& Zhou, Y. (2003). Types of English learning motivation of Chinese undergraduates. Modern Foreign Languages .01:28-38.

[8] Higgs J. (1988). Planning learning experiences to promote autonomous learning. .Developing Student Autonomy. London: Kogan .40-58.

[9] Jin, Y. (2010). Multiple assessment of experienced college English teaching. Chinese Foreign Languages. 7(01):68-76+111.

[10] Li, M., Yu, L., Qin, Y., Lu, P., \& Zhang, X. (2016) .College student academic motivation and engagement in the college English course. The theory \& Practice in Language Studies. 6 (9):1767-1773.

[11] Li, J. Y. \& Liu, P. H. (2015). On the study of foreign language learning motivation in China : A Review (2004-2013). Foreign Language World. (02):34-43.

[12] Liu, S. \& Niu, Z. J. (2018). An empirical study on optimizing the multiple assessment model of English phonetic teaching. Theory and Practice in Foreign Language Teaching. (04):62-68.

[13] Qiu, C. W. (2005). The research and development of second or foreign language learning motivation: A review. Journal of Tianjin Institute of Foreign Languages. (02):57-61.

[14] $\mathrm{Xu}, \mathrm{L}$. (2014). Analysis of the significance of applying multiple evaluation in the process of Experienced college English teaching. Education and Teaching Forum. (21):257-258.

[15] Yang, F. H. (2018). The current situation and innovation of adult English teaching. Industry and Technology Forum. 17 (22):173-174.

[16] Yu, G. (2008). On the multiple assessment system of college English teaching. Research on Higher Education in China. (08):92-93.

[17] Zeng, S. Q. (2018). The role of motivational stimulation in adult oral English classroom teaching. Education and Teaching Forum. (11):197-198.

Zhencong Liu is currently Associate Professor in the School of English Language, Culture and Literature, Beijing International Studies University, China. He received his PH.D degree in linguistics from Beijing Foreign Studies University, China in 2007. His research interests include general linguistics, cognitive linguistics, theory and practice in English teaching. Dr. Liu has published more than 11 textbooks and 30 research papers on cognitive linguistics and applied linguistics.

Ting Li (corresponding author) was born in Shaanxi province, China in 1995. She will receive her Master's Degree in applied linguistics from Beijing International Studies University, China in 2021. Her research interests include second language acquisition, English teaching and discourse analysis.

Huiying Diao was born in Jilin province, China in 1994. She will receive her Master's Degree in applied linguistics from Beijing International Studies University, China in 2021. Her research interests include cognitive linguistics, corpus linguistics and English teaching. 